\title{
PERSEPSI MAHASISWA AKUNTANSI TERHADAP PEMBERLAKUAN ASEAN ECONOMIC COMMUNITY (AEC)
}

\begin{abstract}
Asean Economic Community (AEC) will soon be opened, ASEAN countries have signed the treaty. This is a golden opportunity for every country that has prepared well, but also will be pain for countries that do not or less to prepare for such cooperation. If the AEC materialize in 2015, it is certain that will open employment opportunities as possible for citizens of ASEAN. For Indonesia, the competency of the workforce is generally derived from the development of special skills in a particular field through a college education. This study aims to determine students' knowledge of accounting STIE PGRI Dewantara Jombang against imposing AEC and its implications as well as their readiness in the face of $A E C$. This type of research used in this research is qualitative research using case study approach with descriptive method using primary data obtained through questionnaires. Respondents in this study are students of accounting STIE PGRI Dewantara Jombang. The survey results revealed mostly already know about the implementation of the Asean Economic Community (AEC), but they do not know the consequences of the implementation of the AEC.

Keywords: Student Perceptions, Economic Integration, Employment \& Ecomonic Asean Community (AEC
\end{abstract}

Abstrak

Asean Economic Community (AEC) akan segera dibuka, negara-negara ASEAN telah menandatangani perjanjian tersebut. Hal ini merupakan kesempatan emas bagi setiap negara yang telah mempersiapkan diri dengan baik, namun juga bakal menjadi derita bagi negara-negara yang tidak kunjung atau kurang mempersiapkan diri menghadapi kerjasama tersebut. Apabila AEC terwujud pada tahun 2015, maka dapat dipastikan akan terbuka kesempatan kerja seluas-luasnya bagi warga negara ASEAN. Bagi Indonesia, kompetensi yang dimiliki para tenaga kerja umumnya diperoleh dari pengembangan kemampuan khusus dalam bidang tertentu melalui pendidikan di perguruan tinggi. Penelitian ini bertujuan untuk mengetahui pengetahuan mahasiswa akuntansi STIE PGRI Dewantara Jombang terhadap pemberlakuan AEC dan implikasinya serta kesiapan mereka dalam menghadapi AEC. Jenis penelitian yang digunakan dalam penelitian ini penelitian kualitatif menggunakan pendekatan studi kasus dengan metode deskriptif dengan menggunakan data primer yang diperoleh melalui kuesioner. Responden dalam penelitian ini yaitu mahasiswa program studi akuntansi STIE PGRI Dewantara Jombang. Dari hasil penelitian diketahui sebagian besar sudah mengetahui tentang pemberlakuan Asean Economic Community (AEC) akan tetapi mereka belum mengetahui konsekuensi dari pemberlakuan AEC.

http://ejournal.stiedewantara.ac.id
Keywords : Persepsi Mahasiswa, Integrasi Ekonomi, Kesempatan Kerja \& Asean Ecomonic Community (AEC) 


\section{A. PENDAhULUAN}

Asean Economic Community

(AEC) akan segera dibuka, negara-negara ASEAN telah menandatangani perjanjian tersebut. Tujuan dari perjanjian tersebut adalah setiap negara anggota ASEAN dipersilahkan untuk menjaring konsumen bagi produk-produknya dari negaranegara tetangganya di seluruh kawasan ASEAN. Hal ini merupakan kesempatan emas bagi setiap negara yang telah mempersiapkan diri dengan baik, namun juga bakal menjadi derita bagi negaranegara yang tidak kunjung atau kurang mempersiapkan diri menghadapi kerjasama tersebut. Berbagai persiapan telah dan terus dilakukan oleh setiap negara anggota ASEAN, sehingga bisa memanfaatkan kerjasama tersebut bagi peningkatan perekonomian negara tersebut dan pembangunan negaranya. Menghadapi kerjasama itu, pemerintah Indonesia juga telah mempersiapkan berbagai hal penting bagi kepentingan ekonomi nasional dan kerjasama lainnya di kawasan ASEAN saat pelaksanaan AEC 2015.

\section{ASEAN Economic Community} adalah langkah selanjutnya dari integrasi ekonomi ASEAN menjadi sebuah pasar tunggal dan basis produksi pada tahun 2015. Tujuan integrasi ekonomi akan mencakup penghapusan tarif, gerakan profesional, modal dan prosedur bea cukai lebih cepat. Free Trade Area (FTA) akan menjadi strategi kunci untuk ASEAN untuk mendapatkan akses pasar yang lebih besar ke mitra dagang dan untuk menarik investasi asing langsung ke ASEAN. AEC akan meningkatkan kemakmuran ekonomi regional dan stabilitas dan mengurangi kesenjangan pembangunan di antara anggota.

Prinsip-prinsip pembentukan AEC adalah bahwa ASEAN harus bertindak sesuai dengan prinsip-prinsip ekonomi, terbuka berwawasan ke luar, inklusif dan berorientasi pasar sesuai dengan aturan multilateral serta kepatuhan terhadap aturan-sistem berbasis kepatuhan yang efektif dan pelaksanaan ekonomi komitmen. AEC dikembangkan untuk mengidentifikasi langkah-langkah prioritas dan tindakan dengan target yang jelas dan jadwal yang harus dilakukan untuk membentuk AEC pada tahun 2015. Negara Anggota ASEAN meliputi Brunei Darussalam, Kamboja, Indonesia, Lao PDR, Malaysia, Filipina, Singapura, Thailand, Myanmar dan Vietnam.

Apabila AEC terwujud pada tahun 2015, maka dapat dipastikan akan terbuka kesempatan kerja seluas-luasnya bagi warga negara ASEAN. Dan bagi tenaga kerja terdidik di wilayah ASEAN, rencana penerapan AEC memberi peluang namun juga tantangan. Dikatakan peluang karena seorang tenaga kerja yang tinggal di salah satu negara ASEAN akan punya kesempatan bekerja di sembilan negara ASEAN lain. Dan tentunya dituntut adanya komitmen yang nyata dari seluruh anggota ASEAN atas kesepakatan yang telah dibentuk untuk nantinya dapat ikut berkompetisi dalam liberalisasi perdagangan tersebut. Selain itu segala manfaat yang dapat diraih dari program kerjasama ini hanya dapat diraih dengan persiapan serta daya saing yang baik dari seluruh anggotanya. Dengan kata lain persiapan yang baik perlu dilakukan oleh Indonesia, sebagaimana negara anggota ASEAN lainnya agar dapat menjadi "pemain" dan bukannya hanya sebagai "penonton" dalam sektor aliran bebas barang dalam kerangka AEWC 2015 ini. Sehingga dengan adanya persiapan yang baik tersebut dapat meningkatkan posisi tawar Indonesia khususnya dalam kompetisi liberalisasi perdagangan yang akan terbentuk nantinya.

Hal tersebut tentu mewajibkan kita untuk bersiap diri mengantisipasi segala peluang, tantangan serta dampak positif dan negatif dari AEC ini. AEC yang 
diinterpretasikan sebagai langkah awal bagi suatu kesatuan wilayah ekonomi dan perdagangan di negara-negara ASEAN. Persiapan untuk menghadapi ASEAN community 2015 yang pertama adalah bagaimana menguasai pasar di dalam negeri atau menjadi tuan rumah di negeri sendiri. Untuk itu kita sebagai Sumber Daya Manusia (SDM) harus mempersiapkan semuanya mulai dari sekarang dalam berbagai sektor. Salah satunya adalah sektor pendidikan dan ketenagakerjaan. Masih rendahnya tingkat pendidikan tenaga kerja Indonesia menjadi suatu hal yang tidak bisa dipungkiri menjadi salah satu fokus permasalahan yang harus dituntaskan. Apabila nantinya akan diberlakukan AEC ini, maka seluruh tenaga kerja profesional di seluruh negara ASEAN akan berseliweran masuk ke dalam tiaptiap negara ASEAN, termasuk Indonesia. Hal itu dapat dilakukan dengan mengadakan pelatihan-pelatihan, mengadakan kompetisi-kompetisi untuk mengukur seberapa besar kemampuan yang dimiliki, serta memperhatikan lagi pendidikan yang ada dinegara kita ini. Maka dari pada itu penguatan keprofesionalan sumber daya manusia tenaga kerja dan masyarakat adalah hal yang wajib untuk dilaksanakan. Karena apabila tidak, maka kita akan kalah bersaing dengan tenaga-tenaga profesional di negara-negara ASEAN lainnya. Indonesia akan dipastikan hanya akan menjadi penonton saja, apabila tidak bisa mempersiapkan diri, baik dari segi infrastruktur, SDM dan lain sebagainya untuk menghadapi pasar global ini.

Salah satu tenaga kerja yang akan bersaing dalam ASEAN Economic Community (AEC) 2015 adalah jasa akuntan. Perlu adanya persiapan bagi calon profesi akuntan untuk menghadapi ASEAN Economic Community (AEC) 2015. Persiapan ini akan meningkatkan kualitas Sumber Daya Manusia (SDM) akuntansi Indonesia memiliki daya saing tingkat nasional maupun internasional. Tidak hanya itu, pemerintah juga harus mendukung dengan regulasi yang mendorong peningkatan kualitas jasa profesi dan perkembangan profesi yang ada. AEC 2015 akan berimplikasi pada pasar ASEAN yang akan menjadi lebih terbuka para pemasok jasa. " AEC 2015 akan menguntungkan konsumen karena bisa memilih jasa dengan kualitas yang baik dengan harga bersaing. Itu artinya persaingan akan semakin ketat.

Negara kita Indonesia masuk dalam salah satu negara anggota AEC 2015, yang artinya Indonesia berpeluang untuk memperbaiki perekonomian negara yang semakin hari semakin tertinggal oleh negara-negara tetangga kita. Wamendikbud Prof .Dr. Ir. Musliar Kasim, MS, menekankan adanya tiga pilar yang menjadi kepentingan dalam Era Asean Community 2015. Tiga pilar tersebut yakni keamanan, ekonomi dan sosial. Pemerintah akan lebih meningkatkan ketiga aspek tersebut secara menyeluruh. Namun aspek sosial terutama pendidikan menjadi faktor utama dalam persaingan Asean Community 2015 nantinya.

Berbicara tentang kualitas, maka sangat terkait dengan kompetensi yang dimiliki para tenaga kerja Indonesia. Kompetensi yang dimiliki para tenaga kerja umumnya diperoleh dari pengembangan kemampuan khusus dalam bidang tertentu melalui pendidikan di perguruan tinggi. Melalui perguruan tinggi diharapkan seorang calon tenaga kerja memiliki kompetensi yang memadai. Hal ini menunjukan bahwa pada dasarnya pendidikan di perguruan tinggi memiliki peran yang cukup penting dalam menciptakan lulusan yang memiliki kompetensi tinggi. Namun tidak serta merta hal ini menjadi tanggung jawab dari sekolah atau perguruan tinggi 
semata, niat dan motivasi dari para mahasiswa merupakan modal utama dalam mengembangkan diri mereka sendiri.

Mahasiswa sebagai elemen utama kampus yang merupakan institusi pendidikan tertinggi, selain berkewajiban untuk senantiasa mengembangkan potensi dan memajukan dirinya sendiri, juga sudah selayaknya ikut berperan aktif dalam memanifestasikan ide - idenya yang memberikan manfaat dan kontribusi nyata bagi masyarakat secara luas. Layaknya agent of change, seorang mahasiswa harus mampu membawa perubahan bagi diri dan lingkungannya. Tentu saja untuk mampu membuat perubahan, seorang mahasiswa harus memiliki kompetensi dan ketrampilan khusus di bidangnya. Untuk itu, mahasiswa perlu melakukan kegiatan yang produktif dan inovatif, sehingga diharapkan mampu mengembangkan diri dan memberikan manfaat yang dapat benar-benar dirasakan oleh masyarakat pada umumnya IPK hanya merupakan syarat mutlak untuk mendapatkan pekerjaan selain itu dibutuhkan peningkatan softskill untuk menghadapi tahun 2015.

Liberalisasi jasa akuntan seASEAN pada 2015 nanti tidak bisa dipandang sebelah mata. Maklum saja, akuntan di Indonesia harus bersiap-siap menghadapi persaingan yang semakin ketat dengan akuntan-akuntan negara tetangga. Saat ini, ketika keran liberalisasi belum benar-benar dibuka, akuntan asing sudah menyebar di negeri ini. Tentu saja nanti, ketika gerbang sudah dibentang jangan sampai akuntan Indonesia menjadi tamu di negeri sendiri.

Sekolah Tinggi Ilmu ekonomi (STIE) PGRI Dewantara Jombang merupakan salah satu perguruan tinggi swasta yang ada di Indonesia salah satu program studi yang dimiliki adalah akuntansi. Sebagai perguruan tinggi,
STIE memiliki tanggung jawab moral terhadap penyediaan tenaga kerja yang professional dalam bidang akuntansi. Kabupaten Jombang merupakan salah satu daerah yang potensial, beberapa perusahan multi internasional terdapat di Jombang diantaranya PT. Peihai Internasional Wiratama Indonesia, PT. Cheil Jedang Indonesia serta PT. Mentari Internasional. Perusahaan-perusahaan tersebut merupakan perusahaan yang bergerak dalam bidang manufaktur, berbagai sistem perdagangan ekspor telah dilakukan. Sehingga dengan diberlakukannya AEC maka akan banyak tenaga kerja dalam bidang akuntan dari berbagai Negara ASEAN yang masuk di Indonesia. Di samping itu, tenaga kerja akuntan dari Indonesia yang memiliki kompetensi yang professional juga akan dibutuhkan oleh negara-negara ASEAN pada AEC mendatang.

Dengan demikian Program Studi Akuntansi STIE PGRI Dewantara Jombang harus mampu menghasilkan lulusan akuntan yang professional agar dapat bersaing dalam menghadapi AEC 2015. Penelitian ini merupakan penelitian yang sesuai dengan penelitian yang telah dilakukan oleh Jose Abilio P.S E. Ferdinandes yang melakukan penelitian tentang Persepsi Mahasiswa Terhadap Pemberlakuan Masyarakat Ekonomi Asean. Hasil penelitian tersebut menunjukkan bahwa masih banyak mahasiswa yang belum mengetahui pemberlakuan MEA. Dan dari mahasiswa yang mengetahui tentang MEA, sudah sadar akan dampak yang akan terjadi pada pemberlakuaan MEA dan sudah mulai menyiapkan diri menghadapinya.

Penelitian ini untuk mengetahui pengetahuan mahasiswa akuntansi STIE PGRI Dewantara Jombang terhadap pemberlakuan AEC dan implikasinya serta kesiapan mereka dalam menghadapi AEC. Penelitian ini juga bertujuan sebagai dasar dalam meningkatkan 
proses pembelajaran dan pengembangan kompetensi mahasiswa di bidang akuntansi bagi program studi Akuntansi STIE PGRI Dewantara untuk menghasilkan lulusan akuntansi yang berkompeten dan professional dalam menghadapi persaingan tenaga kerja di Asean Economic Community (AEC).

\section{B. KAJIAN PUSTAKA Persepsi}

Kotler (2012) menjelaskan persepsi sebagai proses bagaimana seseorang menyeleksi, mengatur dan menginterpretasikan masukan-masukan informasi untuk menciptakan gambaran keseluruhan yang berarti. Mangkunegara (2012) berpendapat bahwa persepsi adalah suatu proses pemberian arti atau makna terhadap lingkungan. Dalam hal ini persepsi mecakup penafsiran obyek, penerimaan stimulus (Input), pengorganisasian stimulus, dan penafsiran terhadap stimulus yang telah diorganisasikan dengan cara mempengaruhi perilaku dan pembentukan sikap.

Terkait dengan pemberlakuan AEC, persepsi mahasiswa terhadap pemberlakuan MEA diharapkan akan memberikan gambaran sejauh mana implementasi MEA dipahami oleh mahasiswa sehingga dapat dijadikan salah satu acuan pemerintah dalam menentukan kebijakan-kebijakan terkait MEA yang bersinggungan langsung dengan mahasiswa khususnya dan masyarakat umumnya.

\section{Integrasi Ekonomi}

Jovanovic (2006) mendefinisikan integrasi ekonomi sebagai sebuah proses di mana sekelompok negara berupaya untuk meningkatkan tingkat kemakmurannya. Pelkman (2003) mendefinisikan integrasi ekonomi sebagai integrasi yang ditandai oleh penghapusan hambatan-hambatan ekonomi (economic frontier) antara dua atau lebih ekonomi atau negara. Hambatan-hambatan ekonomi tersebut meliputi semua pembatasan yang menyebabkan mobilitas barang, jasa, faktor produksi, dan juga aliran komunikasi, secara aktual maupun potensial relatif rendah. Dalam (Sholeh, 2013) Integrasi ekonomi adalah rancangan dan implementasi serangkaian kebijakan khusus antar kelompok negara dalam region yang bertujuan untuk meningkatkan pertukaran barang maupun faktor produksi antar negara anggota. Integrasi ekonomi yang terbentuk meliputi integrasi perdagangan dan integrasi moneter.

Salvatore (2007:340) menguraikan ada beberapa jenis integrasi ekonomi :

1. Pengaturan Perdagangan Preferensial (Preferential Trade Arragements) dibentuk oleh negara-negara yang sepakat menurunkan hambatanhambatan perdagangan di antara mereka dan membedakannya dengan negara-negara yang bukan anggota.

2. Kawasan perdagangan bebas (free trade area) di mana semua hambatan perdagangan tarif diantara negaranegara anggota dihilangkan sepenuhnya, namun masing-masing negara anggota masih berhak menentukan sendiri apakah mempertahankan atau menghilangkan hambatan-hambatan perdagangan yang diterapkan terhadap negaranegara non-anggota.

3. Persekutuan Pabean (Customs Union) mewajibkan semua negara anggota untuk tidak hanya menghilangkan semua bentuk hambatan perdagangan di antara mereka, namun juga menyeragamkan kebijakan perdagangan mereka terhadap negara lain non-anggota.

4. Pasaran bersama (Common Market) yaitu suatu bentuk integrasi di mana bukan hanya perdagangan barang saja yang dibebaskan namun arus faktor 
produksi seperti tenaga kerja dan modal juga dibebaskan dari semua hambatan.

5. Uni Ekonomi (Economic Union) yaitu dengan menyeragamkan kebijakankebijakan moneter dan fiskal dari masing-masing negara anggota di dalam suatu kawasan atau bagi negara-negara yang melakukan kesepakatan.

Firdausy (2004) berpendapat bahwa melalui integrasi dan globalisasi diasumsikan setiap negara dapat memperkuat dan memperluas perekonomiannya, meningkatkan kesejahteraan, dan mencapai pembangunan ekonomi yang berkesinambungan. Dasar pertimbangan dari harapan ini karena integrasi ekonomi berarti tidak ada hambatan keluar masuk barang dan jasa serta modal dari suatu negara ke negara lain, sehingga harga barang dan jasa menjadi semakin murah dan tersedia secara memadai di suatu negara. Juga dengan integrasi ekonomi, arus tenaga kerja dari suatu negara ke negara lain dapat menjadi mudah, sehingga tidak akan terjadi kesenjangan antara supply dan demand tenaga kerja di suatu negara. Dengan adanya integrasi ekonomi, maka arus barang, jasa dan uang akan menjadi lebih mudah dibandingkan tanpa integrasi ekonomi. Namun khusus untuk arus tenaga kerja, integrasi ekonomi tidak secara linear akan mendorong arus migrasi. Hayase (2003) dalam Firdausy ((2004), secara tegas menyatakan bahwa arus migrasi tidak secara sederhana dapat terjadi dengan adanya kesepakatan dalam perdagangan dan investasi diAsia Timur. Arus migrasi ke suatu negara juga dipengaruhi oleh faktor sosial, demografi, budaya dan politik. Bahkan menurutnya, banyak fakta menunjukkan besar kecilnya arus migrasi tidak berkaitan dengan adanya integrasi ekonomi. Singkatnya, pengaruh integrasi ekonomi terhadap arus migrasi tenaga kerja nyaris tidak akan terjadi dalam jangka pendek.

Bagi Indonesia peluang terjadinya migrasi tenaga kerja ini berpotensi menguntungkan mengingat tingkat pengangguran Indonesia relative lebih tinggi dari negara ASEAN lainnya. Tingginya penyerapan disektor informal memperlihatkan betapa sebenarnya masih cukup rendah kualitas tenaga kerja Indonesia.

Rendahnya tingkat pendidikan pada tenaga kerja mengakibatkan sulitnya bagi kelompok masyarakat ini untuk mendapatkan pekerjaan formal dengan tingkat keterjaminan yang relatif lebih baik terutama dalam bersaing dengan negara-negara ASEAN lainnya. Potret ini tentunya menjadi kegelisahan yang cukup mengganggu dalam menyongsong pasar tunggal ASEAN, saat arus liberalisasi jasa termasuk jasa profesi baik skillful labor maupun semi-skilled labor akan semakin deras mendekati tahun 2015. Dengan kondisi seperti ini sudah seharunya perlu peningkatan dalam hal kualitas dari para tenaga kerja itu sendiri. Peran serta pemerintah dalam meningkatkan kualitas para pekerja ini sangat diharapkan. Pemerintah sendiri telah menyiapkan 3 strategi dalam meningkatkan kualitas tenaga kerja Indonesia.

Dalam Fernandes (2012) Muhaimin Iskandar mengatakan dalam meningkatkan kompetensi kerja pemerintah menerapkan 3 strategi yaitu peningkatan standar kompetensi kerja, lembaga pendidikan dan pelatihan profesi yang berbasis kompetensi dan sistem dan kelembagaan sertifikasi yang independen terpercaya dan menjamin mutu. Namun keberhasilan dari strategi ini tidak menjamin kualitas tenaga kerja akan meningkat. Kesadaran dari diri sendiri untuk mengubah diri dari para pekerja sendirilah yang paling dibutuhkan dalam 
peningkatan kualitas mereka agar sesuai dengan kompetensi yang dibutuhkan oleh para penyedia kerja.

\section{Kompetensi Kerja}

Kompetensi menurut SK Mendiknas NO.045/U/2002 adalah perangkat tindakan cerdas, penuh tanggung jawab yang dimiliki seseorang sebagai syarat untuk dianggap mampu oleh masyarakat dalam melaksanakan tugas-tugas dibidang pekerjaan tertentu. Menurut Widarno (2007) kompetensi memiliki tiga tingkatan, (1) kompetensi Utama, yaitu kemampuan seseorang untuk menampilkan kinerja yang memadai pada suatu kondisi pekerjaan yang memuaskan, (2) kompetensi pendukung, yaitu kemampuan seseorang yang dapat mendukung kompetensi utama, dan (3) kompetensi lain, yaitu kemampuan seseorang yang berbeda dengan kompetensi utama dan pendukung namun membantu meningkatkan kualitas hidup. Kompetensi ini pada akhirnya akan menentukan daya saing dari tenaga kerja Indonesia, apakah mampu bersaing dengan tenaga kerja asing lainnya.

Spencer dan spencer dalam Yuniarsih (2008:23) menyatakan bahwa Karakteristik kompetensi diklasifikasin dalam 2 jenis, yakni hard skill dan soft skill. Hard skill merupakan kompetensi individu yang dapat diamati dan mudah dikembangkan, misalnya pengetahuan (Knowledege) dan ketrampilan (skill). Sedangkan Softskill adalah kemampuan untuk melaksanakan tugas-tugas fisik dan mental tertentu yang hanya dapat dinilai secara kualitatif melalui observasi perilaku, misalnya self concept, traits dan motive. Paul dan Murdoch dalam Yuniarsih (2008) menjelaskan bahwa dalam menghadapi dunia kerja, seorang lulusan perguruan tinggi harus dilengkapi dengan kualifikasi softskills berikut ini agar dapat bertahan dan unggul dalam kompetisi:
1. Pengetahuan umum dan penguasaan bahasa Inggris.

2. Keterampilan komunikasi meliputi penguasaan komputer dan internet, presentasi audiovisual, dan alat-alat komunikasi lain.

3. Keterampilan personal meliputi kemandirian, kemampuan komunikasi dan kemampuan mendengar, keberanian, semangat dan kemampuan kerjasama dalam tim, inisiatif, dan keterbukaan (etos kerja).

4. Fleksibilitas dan motivasi untuk maju yaitu kemampuan beradaptasi sesuai perubahan waktu dan lingkungan serta keinginan untuk maju sebagai pimpinan.

Selain itu, menurut Mulyatiningsih (2009) dalam Fernandes 2012, pada umumnya perguruan tinggi hanya mengejar target untuk menghasilkan lulusan yang memiliki kompetensi professional saja dan mengabaikan kompetensi kepribadian dan sosial (softskill). Padahal dalam dunia kerja, softskill memiliki kedudukan yang sama pentingnya dengan hardskill. Orang yang memiliki kepribadian baik, bermotivasi tinggi, percaya diri, ulet, tekun, displin, bertanggung jawab dan mampu mengendalikan stress akan memiliki daya tahan yang lebih unggul dalam bekerja.

Akuntan profesional itu memiliki kriteria, di antaranya memiliki register akuntan sesuai dengan peraturan perundangan yang berlaku, memiliki pengalaman atau menjalani keprofesian di bidang akuntansi, baik di sektor korporasi, sektor publik, maupun praktisi akuntan publik. Selain itu seorang akuntan harus taat dan melaksanaan standar profesi, menjaga kompetensi melalui pendidikan profesional berkelanjutan.

Menjelang ASEAN Economic Community 2015, kata Mardiasmo dalam akuntan online 2013, akuntan Indonesia harus siap menghadapi liberalisasi jasa 
akuntan se-ASEAN dalam kerangka AFTA 2015. Para akuntan di Indonesia harus bersiap-siap menghadapi persaingan yang semakin ketat dengan akuntan-akuntan negara tetangga. Mardiasmo mengingatkan, kebutuhan akan akuntan profesional saat ini semakin meningkat dengan adanya tuntutan akan transparansi dan akuntabilitas, baik di sektor swasta maupun pemerintahan. Ikatan Akuntansi Indonesia (IAI) sebagai organisasi profesi, sudah mencanangkan transformasi profesi secara optimal, dengan diawali mengemukakan pengakuan nilai tambah akuntan beregister. Mereka tidak sekedar terdaftar di negara, tetapi betul-betul bermakna sebagai akuntan profesional.

IAI telah meluncurkan professinal designation untuk anggota utama IAI, berupa pemberian sebutan chartered accountant (CA) Indonesia. IAI meluncurkan CA untuk mentaati Statement Membership Obligations Guidelines International Federation of Accountants (IFAC), juga untuk memberi nilai tambah Akuntan Beregister Negara, sebagai persiapan dalam menghadapi ASEAN Economic Community 2015, menyongsong RUU tentang Pelaporan Keuangan, dan juga mensejajarkan Akuntan Profesional Indonesia dengan Gelar Akuntan luar negeri seperti CPA, CA, atau CIMA.

\section{Asean Ecomonic Community (AEC)}

ASEAN economic community (AEC) tahun 2015 merupakan suatu program bagi negara- negara ASEAN untuk lebih meningkatkan kualitas ekonomi khususnya perdagangan agar menjadi sebuah akses yang lebih mudah seperti menerapkan penghapusan bea masuk ( Free Trade Area) untuk mewujudkan sebuah single market (Rimah:2013).

Kawasan AEC diarahkan menjadi suatu kawasan yang kompetitif secara ekonomi dengan tingkat kemajuan yang merata serta terintegrasi penuh ke sistim ekonomi global. Dalam artian perdagangan ini berarti semua barang dapat diperdagangkan dari satu negara ke negara lain di kawasan ASEAN tanpa tariff bea sama sekali. Setiap pengusaha dapat menanamkan modalnya dimana saja dan bahkan menjadi penguasa mayoritas saham di perusahaan manapun di kawasan tersebut (Lolok:2012).

Konsep utama dari ASEAN Economic Community adalah menciptakan ASEAN sebagai sebuah pasar tunggal dan kesatuan basis produksi dimana terjadi free flow atas barang, jasa, faktor produksi, investasi dan modal serta penghapusan tarif bagi perdagangan antar negara ASEAN yang kemudian diharapkan dapat mengurangi kemiskinan dan kesenjangan ekonomi diantara negara-negara anggotanya melalui sejumlah kerjasama yang saling menguntungkan. Kehadiran ASEAN Economic Community bisa membantu ketidakberdayaan negara-negara ASEAN dalam persaingan global ekonomi dunia yaitu dengan membentuk pasar tunggal yang berbasis di kawasan Asia Tenggara. Liberalisasi di bidang jasa yang menyangkut sumber daya manusia mungkin akan tampak terlihat jelas karena menyangkut tentang penempatan tenaga terampil dan tenaga tidak terampil dalam mendukung perekonomian negara. Namun, yang paling banyak berpengaruh dan sangat ditekan dalam ASEAN Economic Community adalah tenaga kerja terampil (Diah:2013).

AEC envisages the following key characteristics: (a) a single market and production base, (b) a highly competitive economic region, (c) a region of equitable economic development, and (d) a region fully integrated into the global economy. The AEC areas of cooperation include human resources development and capacity building; recognition of 
professional qualifications; closer consultation on macroeconomic and financial policies; trade financing measures; enhanced infrastructure and communications connectivity; development of electronic transactions through e-ASEAN; integrating industries across the region to promote regional sourcing; and enhancing private sector involvement for the building of the AEC. In short, the AEC will transform ASEAN into a region with free movement of goods, services, investment, skilled labour, and freer flow of capital (ASEAN, 2012).

\section{METODE PENELITIAN}

Jenis penelitian yang digunakan dalam penelitian ini penelitian kualitatif menggunakan pendekatan studi kasus dengan metode deskriptif. Studi Kasus merupakan penelitian dengan karakteristik masalah yang berkaitan dengan latar belakang dan kondisi saat ini dan subyek yang diteliti serta interaksinya dengan lingkungan. Menurut Sekaran (2009: 46) studi kasus meliputi analisis mendalam dan kontekstual terhadap situasi yang mirip dalam organisasi lain, di mana sifat dan definisi masalah yang terjadi adalah serupa dengan yang dialami dalam situasi saat ini. Menurut Sekaran (2009:158), studi deskriptif dilakukan untuk mengetahui dan menjadi mampu untuk menjelaskan karakteristik variabel yang diteliti dalam suatu situasi.

Hasil akhir dari penelitian studi kasus untuk topik yang sama bisa berbeda antara satu lokasi dengan lokasi lainnya. Demikian pula hasil penelitian pada mahasiswa akuntansi STIE PGRI Dewantara ini juga memiliki kemungkinan berbeda dengan hasil penelitian pada lembaga lainnya.

\section{Proses Pengumpulan dan Analisis Informasi}

Pengumpulan data dilakukan dengan dengan angket atau kuesioner, yakni berisi sejumlah pertanyaanpertanyaan yang harus dijawab atau direspon oleh responden. Responden mempunyai kebebasan untuk memberikan jawaban atau respon sesuai dengan presepsinya. Responden dalam penelitian ini yaitu mahasiswa program studi akuntansi STIE PGRI Dewantara Jombang.

Secara garis besar, terdapat lima tahapan proses pengumpulan data kualitatif.

1. Melakukan identifikasi Subjek/ Partisipan Penelitian dan lokasi Penelitian (Site).

2. Mencari dan Mendapatkan akses menuju Subjek/Partisispan Penelitian dan Lokasi Penelitian .

3. Menentukan Jenis Data yang Akan Dicari/Diperoleh

4. Mengembangkan atau Menentukan Instrumen/Metode Pengumpulan Data.

5. Pengumpulan Data

Penelitian ini menggunakan data primer. Data primer merupakan data yang diperoleh secara langsung dari mahasiswa program studi akuntansi STIE PGRI Dewantara Jombang melalui pengisian kuisioner.

Data dianalisis dengan pendekatan deskriptif dan analitis. Pendekatan deskriptif dilakukan dengan menggambarkan kondisi sebenarnya kemudian dianalisis lebih lanjur sesuai dengan analisis teori maupun penalaran logis untuk menjawab permasalahan yang ada.

Menurut Sukmadinata (2008) langkah-langkah analisis data dapat dimulai dari :

1. Perencanaan. Perencanaan meliputi perumusan dan pembatasan masalah serta merumuskan pertanyaanpertanyaan penelitian yang diarahkan pada kegiatan pengumpulan data. Kemudian merumuskan situasi penilaian, satuan dan lokasi yang 
dipilih serta informan-informan sebagia sumber data. Deskripsi tersebut merupakan pedoman bagi pemilihan dan penentuan sampel purposive.

2. Memulai pengumpulan data. Sebelum pengumpulan data dimulai, peneliti berusaha menciptakan hubungan baik, menumbuhkan kepercayaan serta hubungan yang akrab dengan individu-individu dan kelompok yang menjadi sumber data. Peneliti memulai wawancara dengan beberapa informan yang telah dipilih untuk kemudian dilanjutkan dengan teknik bola salju atau member check. Pengumpulan data melalui interview dilengkapi dengan data pengamatan dan data dokumen (triangualasi). Data pada pertemuan pertama belum dicatat, tetapi data pada pertemuanpertemuan selanjutnya dicatat, disusun, dikelompokkan secara intensif kemudian diberi kode agar memudahkan dalam analisis data.

3. Pengumpulan data dasar. Setelah peneliti berpadu dengan situasi yang diteliti, pengumpulan data lebih diintensifkan dengan wawancara yang lebih mendalam, observasi dan pengumpulan dokumen yang lebih intensif. Dalam pengumpulan data dasar peneliti benar-benar "melihat, mendengarkan, membaca dan merasakan" apa yang ada dengan penuh perhatian. Sementara pengumpulan data terus berjalan, analisis data mulai dilakukan, dan keduanya terus dilakukan berdampingan sampai tidak ditemukan data baru lagi. Deskripsi dan konseptualisasi diterjemahkan dan dirangkumkan dalam diagramdiagram yang bersifat integratif. Setelah pola-pola dasar terbentuk, peneliti mengidentifikasi ide-ide dan fakta-fakta yang membutuhkan penguatan dalam fase penutup.
4. Pengumpulan data penutup. Pengumpulan data berakhir setelah peneliti meninggalkan lokasi penelitian, dan tidak melakukan pengumpulan data lagi. Batas akhir penelitian tidak bisa ditentukan sebelumnya seperti dalam penelitian kuantitatif, tetapi dalam proses penelitian kualitatif akhir masa penelitian terkait dengan masalah, kedalaman dan kelengkapan data yang diteliti. Peneliti mengakhiri pengumpulan data setelah mendapatkan semua informasi yang dibutuhkan atau tidak ditemukan lagi data baru.

5. Melengkapi. Langkah melengkapi merupakan kegiatan menyempurnakan hasil analisis data dan menyusun cara menyajikannya. Analisis data dimulai dengan menyusun fakta-fakta hasil temuan lapangan. Kemudian peneliti membuat diagram-diagram, tabel, gambar-gambar dan bentuk-bentuk pemaduan fakta lainnya. Hasil analisis data, diagram bagan, tabel dan gambar-gambar tersebut diinterpretasikan, dikembangkan menjadi proposisi dan prinsip-prinsip.

\section{Penafsiran dan Penarikan Kesimpulan}

Pada awal proses pengumpulan data primer, peneliti menyebar beberapa kuesioner ke responden, dan dalam penyebaran kuesioner tersebut peneliti dibantu oleh beberapa enumerator. Dari beberapa kuesioner tersebut akan ditentukan pengetahuan mereka tentang pemberlakuan Asean Economic Community (AEC). Kemudian peneliti menyebar lagi kuesioner, namun kali ini peneliti menekankan kepada responden yang tahu dan cukup paham tentang pemberlakuan Asean Economic Community (AEC). Dari kuesioner yang disebar serta penggalian informasi dari responde terkait, peneliti akan menyimpulkan hasil penelitian, sehingga akan diketahui bagaimana persepsi dan 
kesiapan mahasiswa tentang pemberlakuan AEC.

\section{HASIL PENELITIAN DAN PEMBAHASAN}

Penelitian ini dilakukan dengan menyebar 100 kuesioner. Dari 100 kuesioner tersebut yang kembali hanya 52 kuesioner. Dan dari 52 kuesioner tersebut $94 \%$ responden yang mengetahui tentang Assean Economic Community (AEC) akan tetapi, $61 \%$ respondon belum mengetahui dampak dari pemberlakuan AEC. Dilihat dari hasil tersebut, sebenarnya cukup memprihatinkan bahwa sebagian besar mahasiswa belum mengetahu konsekuensi dari pemberlakuan tentang Assean Economic Community (AEC) padahal pada tahun 2015 pemberlakukan AEC sudah harus di mulai. Mahasiswa merupakan kelompok terdidik sebagai salah satu aset penerus bangsa, yang seharusnya mereka lebih siap secara kompetensi dalam menghadapi Assean Economic Community (AEC).

Pengetahuan tentang Assean Economic Community (AEC) atau Masyarakat Economic Asean (MEA)

Berdasarkan jawaban responden diketahui bahwa 61,54 \% responden sudah mengetahui anggota Negara asean dan 94,23 \% responden juga sudah mengetahui tentang AEC / MEA akan tetapi $61,54 \%$ mereka tidak mengetahui konsekuensi dari pemberlakuan Asean Economic Community (AEC).

Berdasarkan hasil penelitian tersebut menunjukkan bahwa perguruan tinggi dalam hal ini program studi akuntansi STIE PGRI Dewantara harus lebih mensosialisasikan konsekuensi dari pemberlakuan AEC, karena sebenarnya cukup memprihatinkan bahwa sebagian besar mahasiswa belum mengetahui konsekuensi dari pemberlakuan Assean Economic Community (AEC), padahal pada tahun 2015 pemberlakukan AEC sudah harus di mulai. Sedangkan mahasiswa merupakan kelompok terdidik sebagai salah satu aset penerus bangsa, yang seharusnya mereka lebih siap secara kompetensi diri dalam bersaing dengan Negara asean lainnya untuk menghadapi Assean Economic Community (AEC)., sehingga mampu memberikan kontribusi yang besar terhadap Negara.

Di samping itu, berdasarkan hasil penelitian di ketahui bahwa $60 \%$ responden mengetahu tentang konsekuensi dari pemberlakuan AEC dari sumber Television kemudian dari internet, dan dari jumlah responden yang tinggal 20 responden karena yang menjawab 'tidak' pada pernyataan pengetahuan tentang konsekuensi terhadap pemberlakuan AEC sudah tidak perlu digali informasi pemahamannya tentang AEC secara mendalam. Dengan demikiaa, $55 \%$ dari responden menyatakan setuju dengan kesepakatan pemberlakuan AEC pada tahun 2015 di Indonesia dengan alasan bahwa Indonesia sudah saatnya siap meningkatkan daya saing bangsa baik melalui produk maupun yang lainnya, akan tetapi $45 \%$ responden menyatakan tidak setuju dengan alasan Indonesia belum cukup siap dalam mengahadapi AEC baik dari sisi produk, tenaga kerja ataupun yang lainnya.

Tabel 1 : Pengetahuan AEC / MEA

\begin{tabular}{|l|l|l|l|l|}
\hline No. & Kategori & \multicolumn{1}{|c|}{ Jawaban } & Frekuensi & \multicolumn{1}{c|}{ Presentasi } \\
\hline \multirow{4}{*}{1.} & Anggota Negara Asean Selain & 9 Negara & 32 & $61,54 \%$ \\
\cline { 3 - 5 } & Indonesia & 8 Negara & 0 & $0,00 \%$ \\
\cline { 3 - 5 } & & 7 Negara & 0 & $0,00 \%$ \\
\cline { 3 - 5 } & 6 Negara & 3 & $5,77 \%$ \\
\cline { 3 - 5 } & 5 Negara & 0 & $0,00 \%$ \\
\hline
\end{tabular}




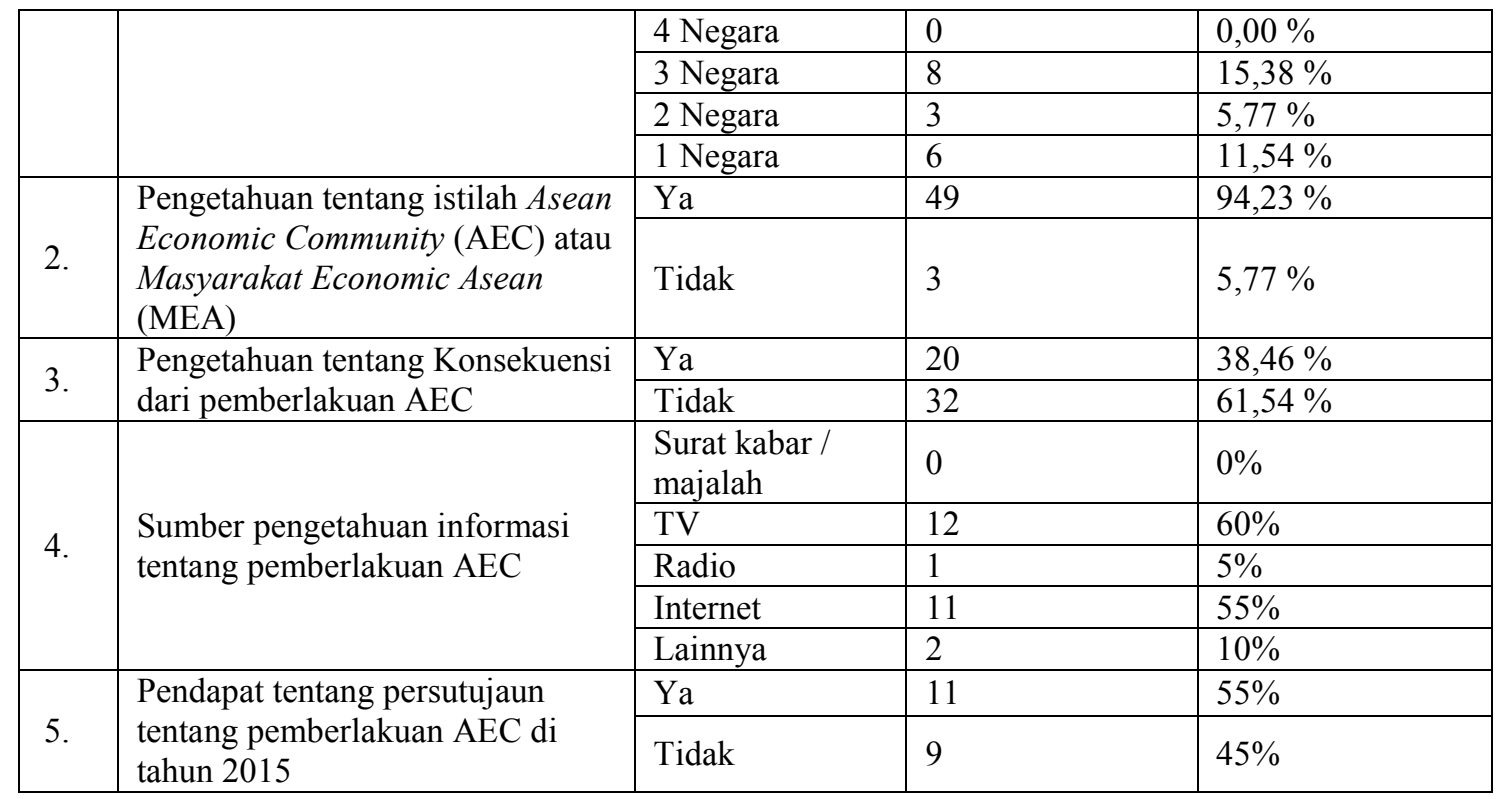

Sumber : Data Diolah

\section{Implikasi Assean Economic Community (AEC)}

Berdasarkan hasil penelitian menunjukkan bahwa masih bayak responden yang belum mengetahui konsekuensi dari pemberlakuan AEC, terutama tentang elemen-elemen pokok yang menjdai pilar utama pelaksanaan AEC. Padahal didalam elemen-elemen itu terdapat elemen tentang arus bebas tenaga kerja terampil, yang mana para mahasiswa terkait didalamnya. Para mahasiswa yang nantinya akan menjadi tenaga kerja terampil akan bersaing dengan tenaga kerja terampil dari Negara asean lainnya saat AEC berlangsung (Fernandes : 2012).

Tabel 2 : Pengetahuan Terhadap Pilar-Pilar AEC

\begin{tabular}{|l|l|l|l|l|}
\hline No. & Kategori & $\begin{array}{l}\text { Sub } \\
\text { Kategori }\end{array}$ & Frekuensi & Prosentasi \\
\hline \multirow{3}{*}{1.} & \multirow{2}{*}{$\begin{array}{l}\text { Pengetahuan terhadap pilar- } \\
\text { pilar utama dalam } \\
\text { pemberlakuan AEC }\end{array}$} & Tidah Tahu & 6 & $30 \%$ \\
\cline { 3 - 5 } & 1 Pilar & 7 & $35 \%$ \\
\cline { 3 - 5 } & 2 Pilar & 0 & $0 \%$ \\
\cline { 3 - 5 } & 3 Pilar & 0 & $0 \%$ \\
\cline { 3 - 5 } & 4 Pilar & 7 & $35 \%$ \\
\hline
\end{tabular}

Sumber : Data Diolah

Hasil penelitian juga menunjukkan bahwa responden belum mengetahui secara mendalam terkait dengan implikasi dari pemberlakuan AEC, baik secara keuntungan terhadap bangsa maupun implikasi terhadap individu. Berikut hasil rekapitulasi jawaban responden terkait dengan implikasi dari pemberlakuan AEC.

Kesiapan Diri dalam Menghadapi Assean Economic Community (AEC)
Berdasarkan hasil penelitian menunjukkan bahwa masih banyak responden yang belum mengetahui konsekuensi dari pemberlakuan AEC, terutama tentang elemen-elemen pokok yang menjdai pilar utama pelaksanaan AEC. Hal tersebut menunjukkan bahwa secara kesiapan diri mahasiswa belum cukup siap dalam menghadapi pemberlakuan AEC baik dari sisi hardskill maupun softskill. 
Dengan demikian, apabila hal tersebut dibiarkan saja maka bisa dipastikan bahwa lulusan program studi akuntansi STIE PGRI Dewantara belum siap dengan pemberlakuan AEC. Oleh karena itu, diperlukan suatu langka yang konstruktif, program studi perlu menambahkan sebuah kompetensi yang unggul dalam mahasiswa, baik hardskill maupun softskill misalnya, penambahan kompetensi melalui program course internal audit atau brivat pajak, bahasa inggris maupun cara berkomunikasi yang baik. Sehingga mahasiswa yang lulus akan memiliki salah satu kompetensi yang dapat di unggulkan dalam menghadapi kebebasan tenaga kerja di tahun 2015.

Disamping

penambahan

kompetensi, kebutuhan softskill juga perlu ditanamkan dalam diri mahasiswa, sehingga menjadi lulusan yang berkompetensi dan bermoralitas tinggi.

\section{E. PENUTUP}

Berdasarkan hasil penelitian dan pembahasan dapat disimpulkan bahwa: Mahasiswa STIE PGRI Dewantara yang menjadi responden sebagian besar sudah mengetahui tentang pemberlakuan Asean Economic Community (AEC) akan tetapi mereka belum mengetahui konsekuensi dari pemberlakuan AEC. Namun demikian, masih banyak responden yang belum mengetahui konsekuensi dari pemberlakuan AEC, terutama tentang elemen-elemen pokok yang menjdai pilar utama pelaksanaan AEC. Padahal didalam elemen-elemen itu terdapat elemen tentang arus bebas tenaga kerja terampil, yang mana para mahasiswa terkait didalamnya. Para mahasiswa yang nantinya akan menjadi tenaga kerja terampil akan bersaing dengan tenaga kerja terampil dari Negara asean lainnya saat AEC berlangsung. Hal tersebut menunjukkan bahwa secara kesiapan diri mahasiswa belum cukup siap dalam menghadapi pemberlakuan AEC baik dari sisi hardskill maupun softskill. Oleh karena itu, diperlukan suatu langka yang konstruktif, program studi perlu menambahkan sebuah kompetensi yang unggul dalam mahasiswa, baik hardskill maupun softskill.

\section{DAFTAR PUSTAKA}

Diah,Martina Purwaning.2013. Sudah Siapkah Indonesia Mengghadapi Asean Economic Community 2015.

http://martinafiaub.wordpress.co $\underline{\mathrm{m}}$

Fernandes, Jose Abilio P.S., 2012. Persepsi Mahasiswa Terhadap Pemberlakuan Masyarakat Ekonomi Asean., Universitas Kristen Satya Wacana

Firdausy, Carunia, 2004, Liberalisasi perdagangan dan investasi di era globalisasi, PPE,LIPI. JAKARTA.

Jovanovic, F., 2006, Integration, disintegration and trade in Europe: Evaluation of trade Relation during the 1990s, Working Paper No. 20.

Kottler, Philip. 2012. Manajemen Pemasaran. Jakarta. Bumi Aksara

Lolok,Adeltus.2012.Seberapa Siapkah Indonesia Menghadapi Asean Economic

Community.http://adeltuslolok.co $\underline{\mathrm{m}}$

Mardiasmo., 2013. Kebutuhan Akuntan Profesional Meningkat., Artikel http://akuntanonline.com

Mulyatiningsih, E. 2009. Analisis Kompetensi. Direktorak PSMK dan Universitas Negeri Yogyakarta.

Pusalia, Retno. 2013. Peran Mahasiswa untuk Indonesia dalam Asean Economic Community (AEC) 2015. Penelitian Ekonomi, 
Fakultas Ekonomi, Universitas Jember

Rimah,Suteja, 2013. Kesiapan Indonesia Hadapi Asean Economic Community.

http://hankam.kompasiana.com

Salvatore, D., 2007. International Economic. $9^{\text {th }}$ Edition. Jakarta. John Wiley \& Sons.

Sekaran, Uma. 2009. Research Methods for Business-Metodologi Penelitian untuk Bisnis Buku 1 Edisi 4. Jakarta: Salemba Empat
Sholeh., 2013. Persiapan Indonesia dalam Menghadapi AEC (Asean Economic Community)., e-Journal Ilmu Hubungan Internasional

Surat Keputusan Mendiknas No. 045/U/2002 tentang kurikulum berbasis kompetensi

Sukmadinata, Nana Sayaodih. 2008.

Metode Penelitian Pendidikan, Bandung : Rosda Karya

Yuniarsih, Tjutju, \& Suwatno., 2008. Manajemen Sumber Daya Manusia : Teori, Aplikasi dan Isu Penelitian. Bandung. Alfabete 